\title{
IMPLEMENTASI LATIHAN KELOMPOK DALAM PEMBELAJARAN SEBAGAI MODEL PEMBIASAAN PERILAKU BELAJAR MAHASISWA PADA MATA KULIAH PENDIDIKAN JASMANI DI SEKOLAH DASAR
}

\author{
Wesly Silalahi \\ Surel:weslysilalahi@gmail.com
}

\begin{abstract}
ABSTRAK
Penelitian ini bertujuan untuk meningkatkan perilaku belajar mahasiswa pada mata kuliah Pendidikan Jasmani di SD pada materi lari sambung (estafet). Subjek penelitan adalah mahasiswa kelas B Ekstensi UNIMED yang berjumlah 36 orang. Penelitian ini adalah penelitian tindakan kelas (PTK) yang dilakukan dalam 2 siklus dimana setiap siklus dilakukan dua kali pertemuan yang masing-masing pertemuan 100 menit. Dari hasil penelitian diperoleh kondisi awal rata-rata perilaku belajar sebesar 2. Pada siklus I dengan rata-rata perilaku belajar latihan kelompok 2,66. Dan pada siklus II, diperoleh data dengan rata-rata perilaku belajar latihan kelompok 3,30 dengan kategori baik, sehingga tidak perlu dilanjutkan ke siklus 3 .
\end{abstract}

Kata kunci: Estafet, Pendidikan Jasmani, Perilaku

\section{PENDAHULUAN}

Peningkatan sumber daya mahasiswa saat ini merupakan salah satu prioritas bangsa kita untuk mempersiapkan daya saing, tuntutan IPTEK dan Era Globalisasi. Perguruan tinggi merupakan salah satu wadah untuk meningkatkan sumber daya manusia melalui pendidikan, penelitian dan pengabdian pada masyarakat dengan segala programnya dalam usaha peningkatan sumber daya manusia. Dalam usaha peningkatan sumber daya manusia dimaksud, Unimed sebagai salah satu lembaga pendidikan tinggi yang dipersiapkan untuk membina generasi muda, perlu terus membenahi diri, terrnasuk di dalamnya pembenahan proses pembelajaran agar berjalan dengan baik untuk menghasilkan tenaga kependidikan yang mampu dan siap menghadapi tantangan di masa depan.

Mata kuliah pendidikan jasmani di SD dengan bobot 2 SKS, merupakan salah satu mata kuliah wajib bagi mahasiswa PGSD FIP Unimed. Mata kuliah ini bertujuan meningkatkan kemampuan mahasiswa merancang, menyusun model pembelajaran dan keterampilan mengajarkannya serta meningkatkan kebugaran jasmani. Mahasiswa PGSD FIP Unimed adalah salah satu lembaga penghasil guru yang diharapkan mampu mengajarkan 5 bidang studi dan juga bidang studi lain, termasuk diantaranya pendidikan jasmani. Hal ini mungkin terjadi untuk mengantisipasi dan mengisi kekurangan guru pendidikan jasmani 
yang berlatar belakang tamatan olahraga atau pendidikan jasmani. Untuk itu perlu membekali setiap mahasiswa agar nantinya terampil mengajarkan materi pendidikan jasmani di SD sesuai dengan yang tertera pada kurikulum agar tujuan pendidikan dapat tercapai. Menurut Toho Cholik M dan Rusli Lutan (1996) bahwa salah satu masalah utama dalam pendidikan jasmani di Indonesia hingga dewasa ini adalah belum efektifnya pengajaran pendidikan jasmani di sekolah dasar, sekolah lanjutan dan bahkan perguruan tinggi. Kondisi ini disebabkan oleh terbatasnya kemampuan guru pendidikan jasmani, terbatasnya sumber-sumber yang digunakan untuk mendukung proses pengajaran dan kualitas guru pendidikan jasmni yang ada pada umumnya kurang memadai. Hal ini tidak perlu dibiarkan terus menerus dan segera perlu diantisipasi agar tujuan pendidikan jasmani yang diharapkan dapat tercapai.

Untuk mempelajari mata kuliah ini, mahasiswa PGSD tidak begitu sulit karena sebenarnya materinya sudah dipelajari dan dilaksanakan pada jenjang pendidikan sekolah dasar, sekolah lanjutan, serta tidak dituntut menjadi seorang atlit atau pemain salah satu cabang olahraga, akan tetapi hanya dituntut mampu melakukan teknik dasar dan mengajarkannya di sekolah dasar sehingga keberhasilan mahasiswa dalam mata kuliah ini tidak terlepas dari penguasan keterampilan melaksanakan teknik dasar materi yang diajarkan. Akan tetapi menurut pengalaman penulis selama ini, pengetahuan dan keterampilan mahasiswa atas materi yang di kandung dalam mata kuliah ini sangat minim sekali. Kalau ditugaskan mahasiswa melakukan teknik dasar yang berkaitan dengan materi pada mata kuliah ini, jarang sekali mahasiswa dapat melakukannya dengan baik, sehingga dituntut peranan dosen untuk membekali mahasiswa tersebut.

Pelaksanaan pembelajaran pendidikan jasmani di PGSD yang berlangsung selama ini masih konvensional dengan metode ceramah dan demonstrasi sebagai pilihan utama tanpa memvariasikan beberapa metode sesuai dengan kebutuhan mahasiswa. Akibatnya mahasiswa kurang bergairah, kurang motivasi atau perilaku belajarnya tidak dengan sungguh-sungguh. Berdasarkan kondisi ini tim dosen pendidikan jasmani melalui Kelompok Dosen Bidang Kajian (KDBK) perlu melakukan kajian mendasar antara lain adalah melakukan penyusunan silabus, Rencana Pelaksanaan Perkuliahan (RPP) dan kontrak perkuliahan sesuai kajian standar kompetensi yang dituntut kurikulum 2007 (KBK) 
dan implementasinya dalam pembelajaran.

Berlatar belakang dari hakikat pengajaran pendidikan jasmani dan pencapaian standar kompetensi pada mata kuliah pendidikan jasmani di SD, maka pembelajaran yang dilakukan dosen seharusnya bervariasi, yaitu memvariasikan metode pembelajaran seperti ceramah, tanya jawab, pemberian tugas, demonstrasi, simulasi, karya wisata, kerja kelompok studi proyek dan sebagainya. Dengan memvariasikan pendekatan dan metode pembelajaran serta sumber-sumber belajar yang relevan pada pembelajaran pendidikan jasmani diharapkan mahasiswa menguasai dan terampil melakukan teknik dasar materi pendidikan jasmani serta terampil mengajarkannya di SD sesuai dengan sistematikanya.

Kenyataan di lapangan ditemui bahwa selama ini dalam pembelajaran pendidikan jasmani di SD, mahasiswa kurang berminat, motivasi belajarnya kurang, perilaku belajarnya kurang, kurang bergairah dalam mengikuti kegiatan pembelajaran yang dilaksanakan oleh dosen. Hal ini terlihat pada saat berlangsungnya kegiatan pembelajaran mahasiswa pasif dan cenderung hanya mengharapkan penjelasan/demonstrasi dari dosen serta selalu berkeinginan agar kegiatan perkuliahan cepat berakhir karena menguras energi. Dari dialog penulis dengan tim KDBK, penulis menganalisis bahwa faktor penyebab terjadinya permasalahan yang dikemukakan di atas adalah rendahnya motivasi belajar mahasiswa atau perilaku belajarnya kurang menunjukkan motivasi yang baik.

Motivasi belajar atau perilaku belajar sangat besar pengaruhnya terhadap unjuk kerja mahasiswa selama dalam pembelajaran dan hasil belajar mahasiswa. Semakin tinggi motivasi atau perilaku belajar mahasiswa cenderung hasil belajar mahasiswa semakin baik. Motivasi atau perilaku belajar mahasiswa dipengaruhi oleh banyak faktor, dan salah satu diantaranya adalah kemampuan dosen dalam mengelola pembelajaran.

Dengan melihat kenyataankenyataan yang terjadi atau permasalahan yang ada pada pembelajaran pendidikan jasmani di SD serta untuk meningkatkan motivasi atau perilaku belajar mahasiswa, maka peneliti mencoba memperbaiki metode pembelajaran dengan latihan kelompok agar pembelajaran menantang pemikiran dan perlu kerjasama (diskusi). Dengan latihan kelompok sebagai model pembiasaan perilaku belajar mahasiswa diharapkan dapat menumbuhkan dan meningkatkan 
motivasi atau perilaku belajar mahasiswa pada taraf yang tinggi dan hasil belajar mahasiswa pada kategori yang baik.

Sebagaimana pada latar belakang masalah, dapat diindentifikasi permasalahan dalam penelitian ini adalah sebagai berikut:

a. Pembelajaran sering sekali berpusat pada dosen

b. Metode yang digunakan dosen kurang bervariasi

c. Mahasiswa kurang antusias dalam mengikuti perkuliahan

d. Mahasiswa kurang memiliki motivasi atau perilaku belajar yang baik

e. Mahasiswa kurang aktif dalam pembelajaran.

f. Mahasiswa kurang berminat dalam belajar

g. Rendahnya hasil belajar mahasiswa

Berdasarkan identifikasi masalah yang ada tersebut diatas, tidak semua di teliti karena keterbatasan waktu, tenaga dan biaya dan juga untuk ketepatan sasarannya maka yang diteliti adalah: model pembelajaran latihan kelompok dalam pembelajaran untuk meningkatkan motivasi atau perilaku belajar mahasiswa PGSD FIP Unimed.

Adapun sebagai rumusan masalah dalam penelitian ini adalah :

Apakah latihan kelompok dapat meningkatkan perilaku belajar mahasiswa Kelas B Ekstensi PGSD FIP Unimed pada materi Lari sambung (estafet)?

Tujuan pelaksanaan penelitian ini adalah untuk mengetahui apakah implementasi latihan kelompok dapat meningkatkan motivasi atau perilaku belajar mahasiswa Kelas B Ekstensi PGSD FIP Unimed.

Manfaat penelitian ini adalah sebagai:

a. Bahan referensi bagi dosen agar merancang dan melaksanakan pembelajaran dengan latihan kelompok sebagai model pembelajaran untuk meningkatkan motivasi atau perilaku belajar mahasiswa.

b. Bahan masukan bagi calon guru dan guru yang mengajar pendidikan jasmani di sekolah dasar untuk menerapkan latihan kelompok sebagai salah satu model pembelajaran untuk meningkaatkan perilaku belajar.

c. Sebagai salah satu alternatif model pembelajaran pada PGSD, khususnya mata kuliah pendidikan jasmani untuk meningkatkan motivasi belajar.

d. Pengalaman yang bermakna bagi mahasiswa PGSD FIP Unimed dalam melaksanakan latihan kelompok untuk meningkatkan perilaku belajar. 


\section{METODE PENELITIAN}

Jenis penelitian yang akan dilaksanakan dalam penelitian ini adalah Penelitian Tindakan Kelas (Classroom Ation Research) yang bertujuan untuk memperbaiki proses pembelajaran untuk meningkatkan perilaku belajar (aktivitas) belajar mahasiswa. Dimana peneliti ini berupaya mengimplementasikan latihan kelompok dalam pembelajaran sebagai model untuk meningkatkan perilaku belajar mahasiswa.

Subjek dalam penelitian ini adalah seluruh mahasiswa PGSD Kelas B Ekstensi NIM 2014 yang mengikuti mata kuliah Pendidikan jasmani di SD sebanyak 1 (satu) kelas atau 36 orang.

Penelitian ini dilaksanakan di FIP UNIMED Jln.William Iskandar Pasar V Medan Estate. Penelitian dilaksanakan pada mahasiswa PGSD Kelas B Ekstensi NIM 2014 Semester III Tahun Akademik 2015/2016

Waktu penelitian ini dilaksanakan selama 2 (dua) bulan, dimulai bulan Oktober 2015 dan dimulai dari tahap.

Penelitian ini menggunakan penelitian tindakan kelas (class action research) untuk menggambarkan aktivitas pembelajaran di kelas, banyaknya indikator pembelajaran yang dapat dicapai dan waktu yang dibutuhkan untuk menyajikan materi.
Desain penelitian ini menggunakan penelitian tindakan kelas (PTK) dengan model yang dikemukakan Kemmis dan $\mathrm{Me}$ Taggart dengan 4 tahap, yaitu: 1). Perencanaan, 2). Tindakan, 3). Observasi dan 4). Refleksi/Evaluasi.

Sesuai dengan jenis penelitian ini yaitu penelitian tindakan kelas yang dilaksanakan sebanyak 2 (dua) siklus, yang mana prosedur pelaksanaannya memiliki beberapa tahapan pelaksanaan tindakan yaitu : 1). perencanaan, 2). tindakan, 3). observasi, dan 4). refleksi.

\section{Siklus 1}

Kegiatan yang dilakukan pada tahap perencanaan adalah merencanakan tindakan yaitu penyusunan skenario pembelajaran. Kegiatan yang dilakukan dalam tahap perencanaan adalah sebagai berikut :

a. Menyusun rencana pembelajaran (RPP) untuk setiap pertemuan yang memuat rencana pembelajaran dengan model pembiasaan perilaku belajar dengan latihan kelompok.

b. Mempersiapkan materi ajar mengenai teknik jalan, lari dan lari sambung (estafet)

c. Menyiapkan tongkat estafet (stick) yang akan digunakan di dalam pembelajaran.

d. Menyusun instrumen penelitian yaitu lembar observasi. 
Setelah perencanaan disusun dengan baik, maka tahap selanjutnya adalah melaksanakan pembelajaran yang telah direncanakan, adapun langkah-langkah pembelajarannya sebagai berikut:

Setelah perencanaan disusun dengan baik, maka tahap selanjutnya adalah melaksanakan pembelajaran yang telah direncanakan, adapun langkah-langkah pembelajarannya sebagai berikut:

a. Pada tahap latihan kelompok, dosen/peneliti membagi mahasiswa ke dalam 8 (delapan) kelompok, dan menyampaikan tujuan pembelajaran.

b. Dosen/peneliti menjelaskan dan mendemonstrasikan teknik lari dan lari sambung

c. Dosen/peneliti menugaskan setiap kelompok melatih teknik lari dan lari sambung.

Kegiatan pengamatan dimaksudkan untuk mengetahui bagaimana pelaksanaan tindakan dapat menghasilkan perubahan yang sesuai dengan yang diharapkan. Terutama perubahan perilaku belajar bagi mahasiswa. Dosen yang lain sebagai observer mengobservasi tentang peneliti dalam mengelola pembelajaran, apakah sesuai dengan rancangan yang telah disusun dan juga mengobservasi perilaku belajar yang terdiri dari perilaku: disiplin, semangat, motivasi, kerjasama, tanggung jawab, sikap sosial, rasa bangga.

Kegiatan ini dilaksanakan padaa akhir pertemuan. Tahap ini mengemukakan kembali secara rinci segala sesuatu yang terjadi dalam pembelajaran selama pertemuan siklus I. Jika pada tahapan siklus masih ditemukan banyak mhasiswa yang belum melakukam perilaku belajar yang baik maka dilaksanakan siklus II, namun jika telah memenuhi tujuan yang diinginkan maka tidak perlu dilakukan tindakan pada siklus selanjutnya, dengan kata lain pembelajaran dianggap selesai.

\section{Siklus II}

Pada tahap ini kegiatan yang dilakukan berupa perbaikan skenario pembelajaran yang disesuaikan hasil refleksi tindakan pada siklus 1 dengan langkah-langkah sebagai berikut:
a. Mengidentifikasi masalah- masalah yang muncul pada siklus
I dan mencari alternatif pemecahan masalah
b. Menyusun rencana pelaksanaan pembelajaran (RPP).
c. Mempersiapkan alat (tongkat estafet) dan perlengkapan lainnya.
d. Menyusun lembar observasi
e. Dokumentasi
Pada tahapan ini kegiatan yang dilakukan adalah merencanakan tindakan penyusunan skenario dengan 
menggunakan latihan kelompok sebagai model pembiasaan perilaku belajar dengan langkah- langkah sebagai berikut:

a. Pada tahap latihan kelompok, dosen/penelitimembagi mahasiswa kedalam 8 (delapan) kelompok, dan menyampaikan tujuan pembelajaran sebagai lanjutan siklus 1 .

b. Dosen/peneliti menjelaskan dan mendemonstrasikan teknik dasar lari sambung dengan memperbaiki kesalahankesalahan pada siklus 1 .

c. Dosen/peneliti menugaskan setiap kelompok melatih teknik dasar lari sambung dengan mengoreksi kesalahan yang dilaksanakan oleh temannya dalam kelompok masing-masing.

Kegiatan pengamatan dimaksudkan untuk mengetahui bagaimana pelaksanaan tindakan dapat menghasilkan perubahan yang sesuai dengan yang diharapkan. Dalam siklus kedua ini penulis juga mengamati kinerja siswa selama pembelajaran berlangsung apakah siswa lebih aktif melaksanakan kegiatan yang dilaksanakan.

Kegiatan ini dilaksanakan pada akhir pertemuan. Tahap ini mengemukakan kembali secara rinci segala sesuatu yang terjadi di kelas selama pertemuan siklus I. Jika pada tahapan siklus masih ditemukan banyak mahasiswa yang berperilaku belajar yang belum baik dalam latihan kelompok maka dilaksanakan siklus III, namun jika telah memenuhi tujuan yang diinginkan maka tidak perlu dilakukan tindakan pada siklus selanjutnya, dengan kata lain pembelajaran dianggap selesai.

Alat yang digunakan dalam pengumpulan data penelitian ini adalah:

Observasi dilakukan untuk mengamati kegiatan pada kelompok selama kegiatan pembelajaran. Observasi dimaksud untuk mengetahui kesesuaian tindakan dengan rencana yang telah disusun dan untuk mengetahui sejauh mana pelaksanakan tindakan dapat dihasilkan perubahan yang sesuai dengan yang dikehendaki. Sebagai alat yang digunakan dengan menggunakan lembar observasi untuk dosen dan lembar observasi motivasi belajar mahasiswa.

Alat yang digunakan dalam pengumpulan data pada penelitian ini dilaksanakan dengan observasi.

Observasi yang dilakukan merupakan pengamatan terhadap seluruh kegiatan pengajaran dan perubahan yang terjadi pada saat dilakukannya pemberian tindakan dan lembar observasi tersebut ditujukan bagi peneliti dan mahasiswa.

Analisis data dilaksanakan penulis sejak awal, pada setiap aspek kegiatan penelitian mulai dari observasi dilengkapi dengan catatan 
terhadap apa yang diamati. Data yang diperoleh dalam penelitian dianalisis dengan menggunakan model analisis data deskriptif kuantitatif. Dimana penelitian ini lebih memperhatikan hasil observasi perilaku belajar mahasiswa

Hasil pengamatan yang telah dilakukan pengamat dikembalikan kepada peneliti untuk dianalisis. Untuk penilaian pengamatan dapat diberi nilai berdasarkan kriteria skor:

SB : Sangat Baik (4)

C : Cukup Baik (2)

B : Baik (3)

K : Kurang Baik (1)

Perhitungan hasil pengamatan dapat dilakukan dengan rumus sebagai berikut:

$$
\mathrm{P}_{\mathrm{i}}=\frac{f}{n} \times 100 \%
$$

Keterangan:

$\mathrm{P}_{\mathrm{i}}=$ Persentasi hasil pengamatan pada pertemuan ke- $\mathrm{i}$

$\mathrm{f}=$ Jumlah aspek yang diamati

$\mathrm{n}=$ skor total

Untuk menentukan taraf perubahan proses belajar mahasiswa dengan nilai yang dicapai adalah menggunakan standart/penilaian sebagai berikut :

p-ISSN 2407-4934

e-ISSN 2355-1747
Tabel 1. Kriteria Tingkat Keberhasilan Belajar Mahasiswa dalam \%

\begin{tabular}{|c|c|}
\hline $\begin{array}{c}\text { Tingkat Keberhasilan } \\
(\%)\end{array}$ & Arti \\
\hline$>80 \%$ & Sangat tinggi \\
\hline $60-79 \%$ & Tinggi \\
\hline $40-59 \%$ & Sedang \\
\hline $20-39 \%$ & Rendah \\
\hline$<20 \%$ & $\begin{array}{c}\text { Sangat } \\
\text { rendah }\end{array}$ \\
\hline
\end{tabular}

Kategorisasi ini dikemukakan oleh, Aqib Zainal (2009)

\section{HASIL DAN PEMBAHASAN}

Langkah pertamayang dilakukan oleh peneliti adalah melakukan kegiatan pengamatan terhadap perilaku belajar atau motivasi mahasiswa pada saat pembelajaran di lapangan dengan menggunakan alat bantu berupa Daftar Checklist. Untuk melihat gejala perilaku atau motivasi belajar mahasiswa pada saat kegiatan latihan dilapangan yang ditandai separti perilaku belajar mahasiswa yang dilihat indikator-indikator perilaku belajar, diantaranya adalah : tekun menghadapi tugas, ulet menghadapi kesulitan, menunjukkan minat terhadap bermacam-macam masalah, lebih senang bekerja mandiri, tidak mudah jenuh dalam proses pembelajaran, dapat mempertahankan pendapatnya, dan senang mencari dan memecahkan masalah. 
Kelas yang diobservasi adalah mahasiswa PGSD kelas B Extensi NIM 2014 dengan menggunakan daftar checklist dimana untuk mengetahui sejauh mana motivasi belajar awal belajar mahasiswa pada pembelajaran materi lari jarak dekat sehingga hasil observasi yang dapat disimpulkan bahwa motivasi belajar mahasiswa masih tergolong rendah.

Dari hasil pengamatan tersebut, yang menjadi salah satu hambatan yang dilihat adalah penggunaan metode pembelajaran yang digunakan dosen kurang bervariasi, yaitu hanya metode ceramah dan demonstrasi saja. Karena itu untuk meningkatkan motivasi belajar mahasiswa perlu memvariasikan metode mengajar sebagai salah satu alternatif untuk meningkatkan motivasi belajar mahasiswa. Karena itu diambil suatu kebijaksanaan dengan menginovasi pembelajaran yang dilakukan peneliti dengan mengimplementasikan latihan kelompok dalam pembelajaran.

Dari data hasil observasi yang dilakukan dapat diketahui bahwa perilaku belajar latihan kelompok mahasiswa PGSD kelas B Extensi masih tergolong rendah, hal ini dapat dilihat dari:

1. Ada 4 orang mahasiswa dari 36 mahasiswa yang memperoleh hasil yang baik dengan nilai antara 2,80-3,39 sebesar $11,11 \%$ dari observasi pada kondisi awal.
2. Ada 4 orang mahasiswa dari 36 mahasiswa yang memperoleh hasil yang cukup dengan nilai antara 2,60-2,79 sebesar $11,11 \%$ dari observasi pada kondisi awal.

3. Ada 28 orang mahasiswa dari 36 mahasiswa yang memperoleh hasil yang kurang dengan nilai antara 0,00-2,59 sebesar $77,78 \%$ dari observasi pada kondisi awal.

Lebih jelasnya perilaku belajar mahasiswa pada kondisi awal sebelum dilakukan perlakuan pembelajaran dengan latihan kelompok dapat dilihat seperti pada gambar diagram batang dibawah ini:

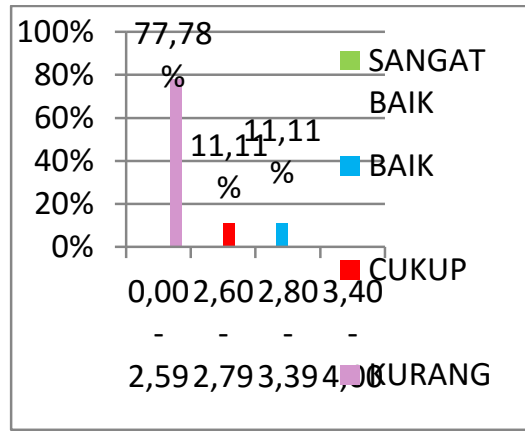

Gambar 1. Diagram Perilaku Belajar Mahasiswa pada kondisi awal

\section{Deskripsi Siklus I}

Pada kegiatan ini tindakan dilakukan peneliti bersama dosen lain sebagai teman kolaborasi dengan menerapkan metode latihan kelompok yang bertujuan untuk meningkatkan motivasi atau perilaku belajar mahasiswa khususnya dalam pembelajaran mata kuliah pendidikan 
jasmani di sekolah dasar pada materi lari sambung (estafet).

Perencanaan yang dilakukan dalam penelitian ini adalah untuk membuat alternatif pemecahan masalah dengan melaksanakan pembelajaran menggunakan metode latihan kelompok dengan urutan langkah-langkah sebagai berikut:

a. Membuat Rencana Pelaksanaan Pembelajaran (RPP) sebagai skenario pembelajaran yang sesuai dengan materi lari sambung (estafet).

b. Mempersiapkan lembar observasi untuk mengetahui sejauh mana motivasi belajar mahasiswa dalam latihan kelompok selama tindakan penelitian diterapkan.

c. Mempersiapkan tongkat (stick) untuk lari sambung (estafet) sebanyak 40 batang.

Pada tahap pelaksanaan tindakan ini, kegiatan peneliti (dosen) lebih difokuskan kepada pembelajaran dengan menggunakan metode latihan kelompok pada siklus I. Sebelum pembelajaran dimulai, peneliti meminta kepada salah seorang mahasiswa untuk memimpin latihan pemanasan (warming-up) untuk keseluruhan mahasiswa dengan tujuan agar seluruh mahasiswa sudah mempersiap diri untuk menerima bentuk latihan yang lebih berat. Kemudian membagi kelompok atas: 9 (sembilan) kelompok dan memberikan apersepsi.

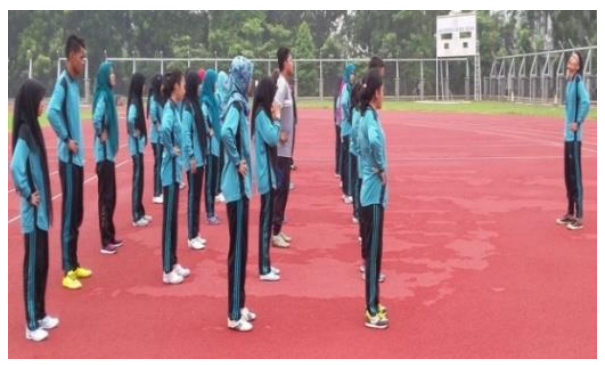

Gambar 2. Latihan pemanasan

Kegiatan berikutnya, peneliti memotivasi mahasiswa agar lebih bersemangat belajar mengikuti kegiatan pembelajaran dan kemudian peneliti menyampaikan tujuan pembelajaran yang akan dicapai selama 2 x 50 menit. Kemudian peneliti mendemonstrasikan teknik lari sambung, yaitu teknik lari dan pertukaran tongkat.

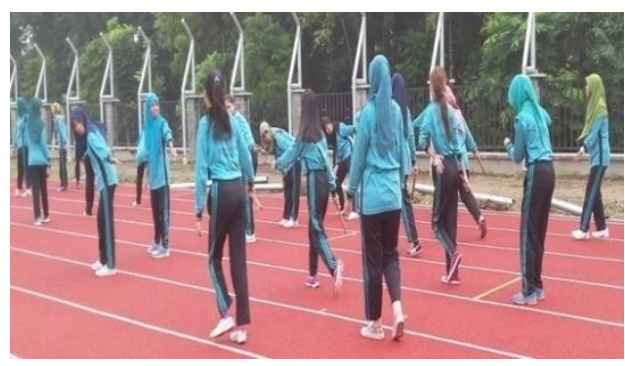

Gambar 3. Teknik lari sambil pertukaran tongkat

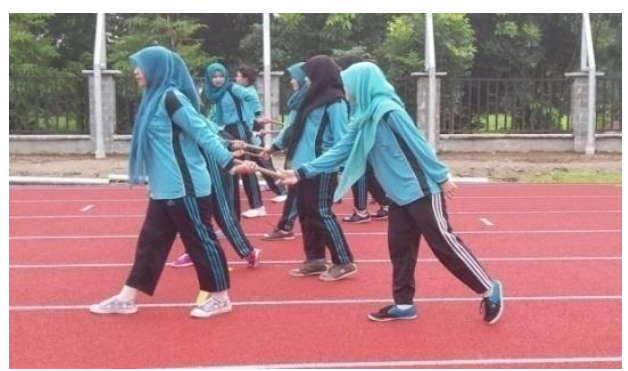

Gambar 4. Teknik pertukaran tongkat 
Selanjutnya menugaskan setiap kelompok untuk latihan pada kelompok masing-masing sambil berdiskusi dan peneliti mengamati setiap kelompok untuk latihan. Bila ada teknik yang kurang baik setiap orang pada setiap kelompok langsung memperbaikinya tanpa menunggu waktu sambil memberi apresiasi kepada kelompok yang terbaik sehingga tercipta persaingan secara sehat dengan sendirinya dan setiap kelompok berusaha latihan dengan sebaik-baiknya sehingga secara langsung atau tidak langsung terjadi peningkatan motivasi berlatih (belajar).

Pada akhir siklus I, peneliti menugaskan kepada kelompok yang terbaik untuk mendemonstrasikan teknik dasar lari sambung dan memberi penguatan kepada kelompok tersebut sehingga kelompok lain akan berusaha untuk mencapai yang terbaik pada pembelajaran berikutnya. Selanjutnya, peneliti bersama mahasiswa menyimpulkan materi pembelajaran dan menugaskan mahasiswa untuk mempelajari pembelajaran berikutnya, yaitu: teknik start dan melewati garis finish.

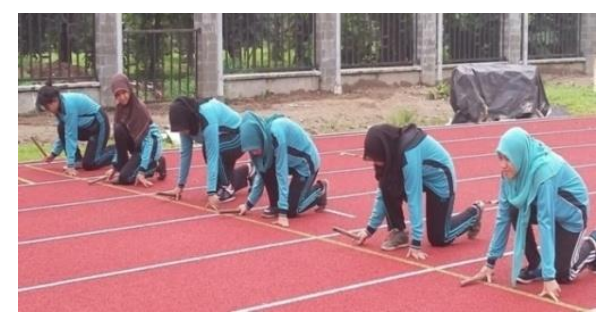

Gambar 5. Teknik "Start"

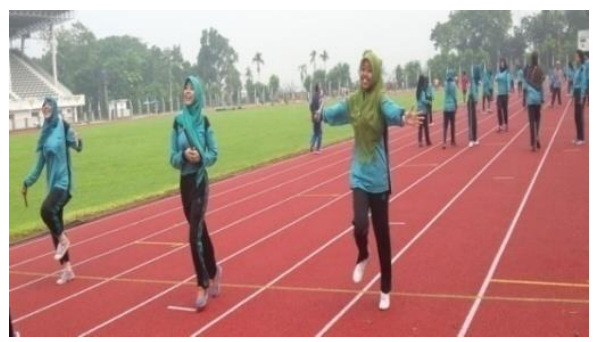

Gambar 6. "Teknik melewati garis finish"

Sebelum pembelajaran diakhiri, peneliti meminta kepada tiap kelompok untuk menyampaikan kekurangan dan teknik lari sambung (estafet) yang belum dikuasai atau belum terampil melaksanakannya. Selanjutnya peneliti bersama mahasiswa menyimpulkan hasil pembelajaran yang sudah dicapai dan harapan yang belum dikuasai oleh mahasiswa.

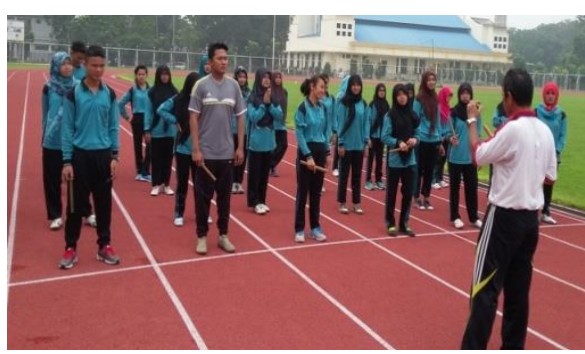

\section{Gambar 7. Peneliti menjelaskan dan menyimpulkan kegiatan latihan kelompok}

Pada saat pelaksanaan tindakan I, peneliti meminta dosen lain sebagai teman kolaborasi untuk mengobservasi peneliti dengan menggunakan lembar observasi dalam melaksanakan kegiatan pembelajaran. Observasi dilakukan untuk melihat motivasi mahasiswa 
ketika latihan kelompok selama pembelajaran berlangsung. Dan juga mengobservasi kemampuan peneliti melaksanakan pembelajaran apakah sesuai dengan skenario (RPP) pembelajaran yang telah disusun terlebih dahulu sebelum pembelajaran dilaksanakan.

Berdasarkan hasil observasi yang telah dilakukan pada siklus I, maka peneliti melakukan refleksi terhadap seluruh kegiatan pada siklus I dengan hasil sebagai berikut:

a. Ada sebagian mahasiswa yang masih kurang aktif, kurang tekun karena didominasi oleh ketua kelompok

b. Hanya sebagian mahasiswa yang mampu menguasai materi teknik lari dan pertukaran tongkat, namun masih banyak mahasiswa belum dapat bekerjasama

c. Kebanyakan dari mahasiswa masih kurang aktif dan memperhitungkan kelelahan akibat banyak bergerak serta cepat bosan karena menguras energi.

Meskipun hasil siklus I belum sesuai dengan yang diharapkan dan perlu dikaji ulang kembali pada pengembangan pembelajaran pada siklus II dan diharapkan adanya peningkatan motivasi belajar mahasiswa secara optimal.

Berdasarkan hasil observasi yang telah dilakukan oleh observer pada siklus I maka diperoleh hasil sebagai berikut :

1. Ada 1 orang mahasiswa dari 36 orang mahasiswa yang mengalami perubahan dengan memperoleh hasil yang baik sekali dengan nilai antara 3,404,00 sebesar $2,78 \%$ dari observasi setelah dilakukannya tindakan siklus I.

2. Ada 12 orang mahasiswa dari 36 mahasiswa yang mengalami perubahan dengan memperoleh hasil yang baik dengan nilai antara 2,80-3,39 sebesar $33,33 \%$ dari observasi setelah dilakukannya tindakan siklus I.

3. Ada 5 siswa dari 36 mahasiswa yang memperoleh hasil yang cukup dengan nilai antara 2,602,79 sebesar $13,89 \%$ dari observasi setelah dilakukannya tindakan siklus I.

4. Ada 18 orang mahasiswa dari 36 mahasiswa yang memperoleh hasil yang kurang dengan nilai antara 0,00-2,59 sebesar 50,0\% dari observasi setelah dilakukannya tindakan siklus I.

Lebih jelasnya Perilaku belajar mahasiswa pada siklus I setelah dilakukan perlakuan pembelajaran dengan latihan kelompok dapat dilihat seperti pada gambar diagram batang dibawah ini: 


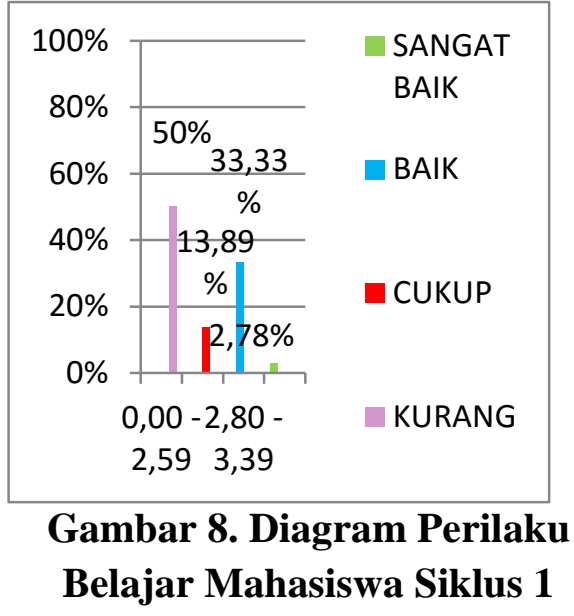

\section{Deskripsi Siklus II}

Pada kegiatan ini tindakan dilakukan peneliti bersama dosen Penjas yang lain sebagai teman berkolaborasi dengan menekankan kekurangan pada siklus I, seperti ketekunan, kerjasama, cepat bosan dan menjelaskan kekurangankekurangan pada siklus I serta menciptakan latihan dengan berlomba menguasai keterampilan teknik dasar lari sambung (estafet).

Perencanaan yang dilakukan dalam penelitian selanjutnya untuk memecahkan permasalahan yang belum terpecahkan dalam pembelajaran dengan langkahlangkah sebagai berikut :

1. Menyusun Rencana Pelaksanaan Pembelajaran (RPP) yang sesuai dengan materi teknik start, teknik melewati garis finish serta kombinasi antara: taknik start, teknik lari, teknik pertukaran tongkat dan teknik melewati garis finish dengan penekanan kepada ketekunan latihan kelompok, bekerjasama, menciptakan suasana agar tidak bosan dengan pembelajaran yang bersifat bermain dan berlomba.

2. Menyiapkan lembar observasi untuk mengetahui hasil motivasi belajar siswa selama tindakan penelitian dilakukan dan lembar observasi kemampuan dosen menerapkan RPP.

3. Menyediakan tongkat (stick) untuk lari sambung (estafet).

Pada tindakan siklus II, rencana pembelajaran dilaksanakan dua kali pertemuan dengan masingmasing pertemuan selama $2 \times 50$ menit. Pada pelaksanaan tindakan siklus II ini, peneliti tetap menggunakan model pembelajaran latihan kelompok dan memadukannya dengan berlomba pada lintasan lari yang sebenarnya. Peneliti menjelaskan dan diperagakan oleh kelompok mahasiswa teknik start dan teknik melewati garis finish.

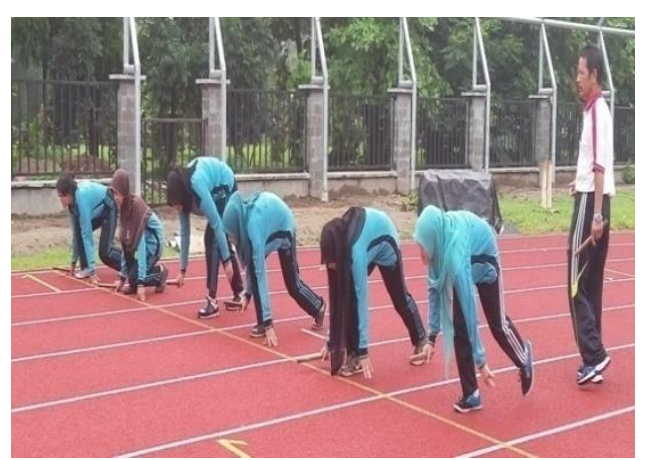

Gambar 9. Teknik Start 


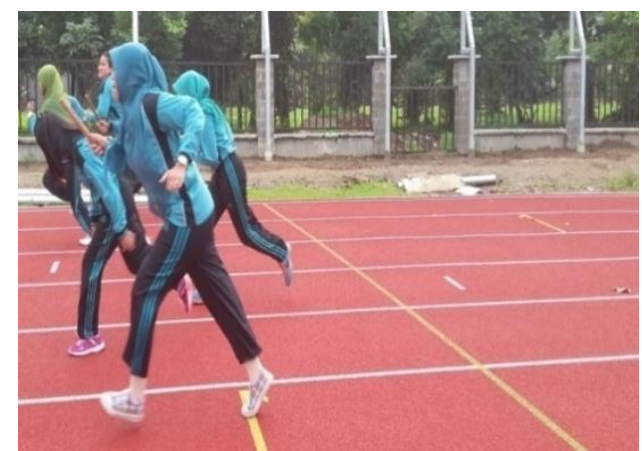

Gambar 10. Teknik melewati garis finish

Selanjutnya

peneliti

menjelaskan teknik penempatan posisi pertukaran tongkat estafet agar pada saat pertukaran tongkat tidak terjadi tabrakan antara pemberi tongkat dengan penerima tongkat dan diperagakan oleh mahasiswa sendiri. Kemudian peneliti menugaskan mahasiswa melakukan latihan pada kelompok masing-masing teknik/posisi pemberian dan penerimaan tongkat estafet.

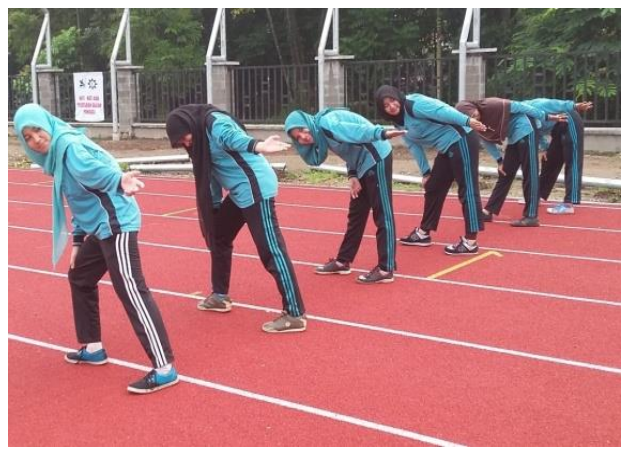

Gambar 11. Penempatan posisi pertukaran tongkat
Selanjutnya

peneliti memotivasi dan menjelaskan kombinasi teknik lari sambung (estafet), yaitu teknik start, teknik lari, posisi penerimaan dan pemberian tongkat dan teknik melewati garis finish. Kemudian setiap kelompok ditugaskan latihan pada kelompok masing-masing. Saat mahasiswa latihan dalam kelompok masingmasing, peneliti memperhatikan dan memperbaiki teknik lari estafet yang masih belum dan perlu diperbaiki dan pengamat (observer) mengamati motivasi mahasiswa untuk selama pembelajaran berlangsung.

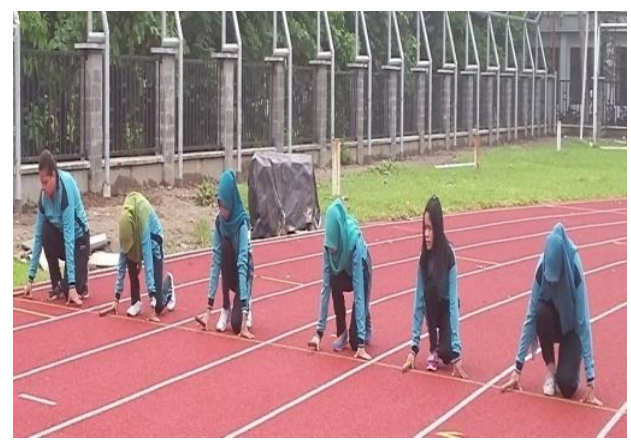

Gambar 12. Teknik start

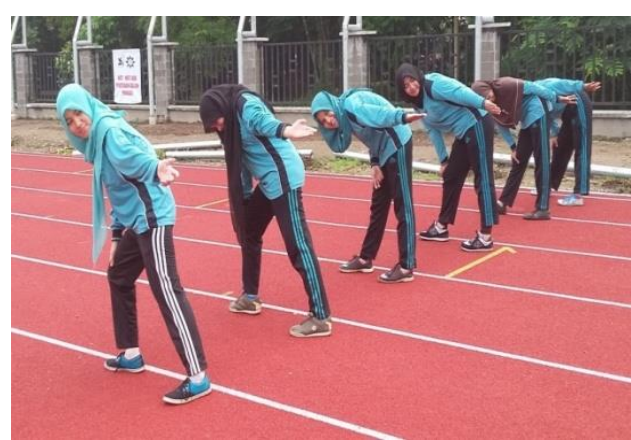

Gambar 13. Penempatan posisi penerimaan dan pemberian tongkat estafet. 


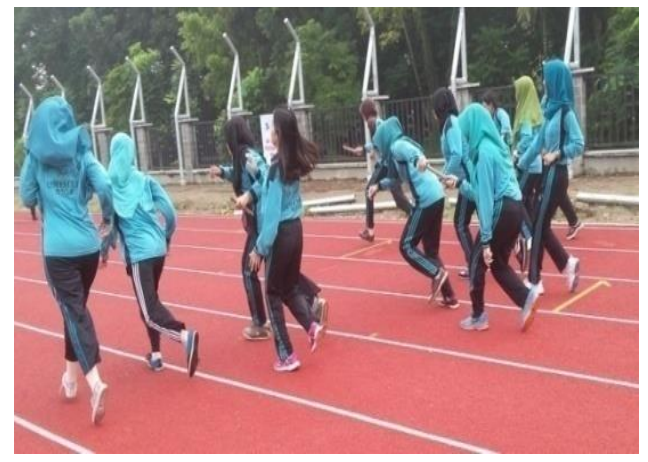

Gambar 14. Teknik lari sambil memberi tongkat (pertukaran tongkat)

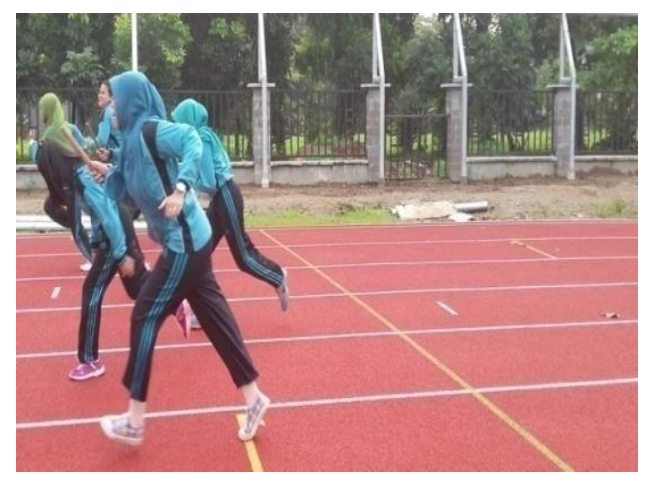

\section{Gambar 15. Teknik lari melewati garis finish}

Setelah selesai masingmasing mahasiswa berlatih dalam kelompok, dan dievaluasi apakah telah menguasai teknik lari estafet, selanjutnya setiap kelompok diperlombakan untuk melihat dan menambah motivasi atau perilaku belajar mahasiswa. Pada akhir pembelajaran peneliti memberi arahan teknik-teknik yang belum sempurna dan kegiatan tindak lanjut untuk melatih anak-anak SD.

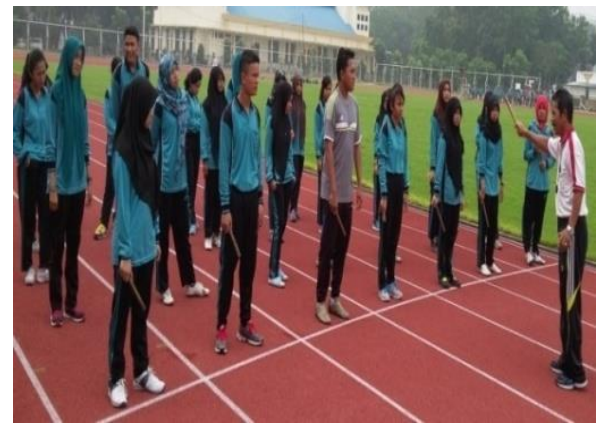

Gambar 16. Peneliti memberi arahan dan kesimpulan latihan kelompok

Kegiatan pengamatan dilakukan oleh observer yaitu: dosen pengampu mata kuliah Pendidikan Jasmani yang berkolaborasi dengan peneliti untuk mengobservasi motivasi setiap mahasiswa yang berlatih dalam kelompok selama pembelajaran berlangsung, dan juga mengobservasi kemampuan peneliti menerapkan RPP yang telah disusun sebelum tindakan siklus II.

Berdasarkan hasil observasi yang telah dilakukan oleh observer pada siklus II, maka diperoleh hasil sebagai berikut:

1. Ada 16 orang mahasiswa dari 36 orang mahasiswa yang mengalami perubahan dengan memperoleh hasil yang sangat baik dengan nilai antara 3,40 4,00 atau sebesar $44,44 \%$.

2. Ada 19 orang mahasiswa dari 36 mahasiswa yang mengalami perubahan dengan memperoleh hasil yang baik dengan nilai antara 2,80-3,39 atau sebesar $52,78 \%$. 
3. Ada 1 orang mahasiswa dari 36 mahasiswa yang memperoleh hasil yang cukup dengan nilai antara 2,60-2,79 sebesar 2,78\%.

\section{Lebih jelasnya perilaku} belajar mahasiswa pada siklus I setelah dilakukan perlakuan dengan implementasi latihan kelompok dapat dilihat seperti pada gambar diagram batang di bawah ini:

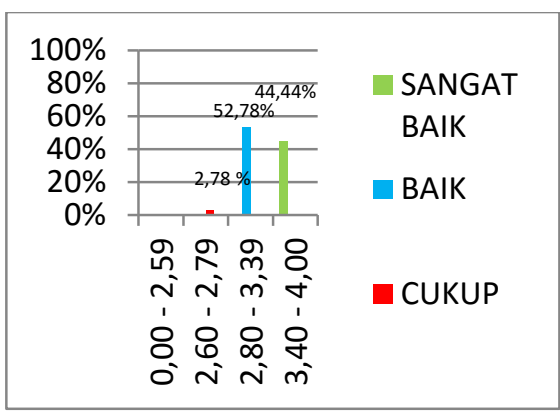

\section{Gambar 17. Diagram Perilaku Belajar Mahasiswa Siklus 2}

Dari hasil pengamatan (observasi) yang dilakukan secara keseluruhan terjadi peningkatan motivasi latihan kelompok dalap pembelajaran materi lari sambung (estafet) pada mata kuliah Pendidikan Jasmani di Sekolah Dasar. Jadi penelitian dan pelaksanaan siklus diakhiri hanya melakukan siklus II saja karena sudah menunjukkan peningkatan dan ketuntasan perilaku belajar mahasiswa.

\section{Pembahasan Hasil Penelitian}

Hasil penelitian yang dilakukan pada mahasiswa B Extensi PGSD FIP Unimed NIM 2014 menunjukkan bahwa penerapan metode Latihan kelompok dapat meningkatkan motivasi belajar mahasiswa pada materi lari sambung (estafet) dan menunjukkan hasil yang baik. Dapat dilihat pada tabel di bawah:

Tabel 4. Hasil Observasi Perilaku Belajar mahasiswa Pada Kondisi Awal, Siklus I, dan Siklus II

\begin{tabular}{|c|c|c|c|c|c|c|l|}
\hline \multirow{2}{*}{$\begin{array}{c}\text { NO. } \\
\text { Urut }\end{array}$} & \multicolumn{2}{|c|}{ Kondisi Awal } & \multicolumn{2}{|c|}{ Siklus I } & \multicolumn{2}{|c|}{ Siklus II } & \multirow{2}{*}{ Keterangan } \\
\cline { 2 - 8 } & Nilai & Ketegori & Nilai & Ketegori & Nilai & Kategori & \\
\hline 1 & 2,43 & Kurang & 2,86 & Cukup & 3,14 & Baik & Meningkat \\
\hline 2 & 2,57 & Kurang & 3,29 & Baik & 3,71 & Baik & Meningkat \\
\hline 3 & 2,43 & Kurang & 2,86 & Baik & 3 & Baik & Meningkat \\
\hline 4 & 2,43 & Kurang & 2,71 & Cukup & 3,86 & Baik Sekali & Meningkat \\
\hline 5 & 2,29 & Kurang & 2,57 & Kurang & 3,86 & Baik Sekali & Meningkat \\
\hline 6 & 1,86 & Kurang & 2,28 & Kurang & 3,14 & Baik & Meningkat \\
\hline 7 & 2 & Kurang & 2,28 & Kurang & 2,86 & Baik & Meningkat \\
\hline 8 & 3,14 & Baik & 3,43 & Baik & 3,57 & Baik Sekali & Meningkat \\
\hline
\end{tabular}


ESJ VOLUME 6, NO. 1, DESEMBER 2016

\begin{tabular}{|c|c|c|c|c|c|c|c|}
\hline 9. & 1,86 & Kurang & 2,28 & Kurang & 2,86 & Baik & Meningkat \\
\hline 10. & 3 & Cukup & 3,29 & Baik & 3,57 & Baik Sekali & Meningkat \\
\hline 11 & 2,43 & Kurang & 2,71 & Cukup & 3,43 & Baik Sekali & Meningkat \\
\hline 12 & 3,14 & Baik & 3,43 & Baik & 3,71 & Baik Sekali & Meningkat \\
\hline 13 & 2,57 & Kurang & 2,86 & Baik & 3,86 & Baik Sekali & Meningkat \\
\hline 14 & 2 & Kurang & 2,28 & Kurang & 2,71 & Cukup & Meningkat \\
\hline 15 & 3 & Baik & 3,43 & $\begin{array}{c}\text { Baik } \\
\text { Sekali }\end{array}$ & 3,71 & Baik Sekali & Meningkat \\
\hline 16 & 2,86 & Cukup & 3,14 & Baik & 3,57 & Baik Sekali & Meningkat \\
\hline 17 & 1,86 & Kurang & 2,28 & Kurang & 2,86 & Baik & Meningkat \\
\hline 18 & 2,43 & Kurang & 2,86 & Baik & 3 & Baik & Meningkat \\
\hline 19 & 2,29 & Kurang & 2,57 & Kurang & 3 & Baik & Meningkat \\
\hline 20 & 2,86 & Cukup & 3,14 & Baik & 3,86 & Baik Sekali & Meningkat \\
\hline 21 & 2,57 & kurang & 3 & Baik & 3,14 & Baik & Meningkat \\
\hline 22 & 1,86 & Kurang & 2,28 & Kurang & 3,43 & Baik Sekali & Meningkat \\
\hline 23 & 2 & Kurang & 2,28 & Kurang & 2,86 & Baik & Meningkat \\
\hline 24 & 1,86 & Kurang & 2,14 & Kurang & 3,14 & Baik & Meningkat \\
\hline 25 & 2 & Kurang & 2,28 & Kurang & 3 & Baik & Meningkat \\
\hline 26 & 2,14 & Kurang & 2,57 & Kurang & 2,86 & Baik & Meningkat \\
\hline 27 & 2 & Kurang & 2,28 & Cukup & 3,86 & Baik Sekali & Meningkat \\
\hline 28 & 3 & Baik & 3,28 & Baik & 3,71 & Baik Sekali & Meningkat \\
\hline 29 & 2,43 & Kurang & 2,71 & Cukup & 3 & Baik & Meningkat \\
\hline 30 & 2 & Kurang & 2,28 & Kurang & 2,86 & Baik & Meningkat \\
\hline 31 & 2,14 & Kurang & 2,42 & Kurang & 3,86 & Baik Sekali & Meningkat \\
\hline 32 & 1,86 & Kurang & 2,28 & Kurang & 2,86 & Baik & Meningkat \\
\hline 33 & 1,71 & Kurang & 2,28 & Kurang & 3 & Baik & Meningkat \\
\hline 34 & 2,14 & Kurang & 2,57 & Kurang & 3,57 & Baik Sekali & Meningkat \\
\hline 35 & 1,86 & Kurang & 2,14 & Kurang & 2,86 & Baik & Meningkat \\
\hline 36 & 2,57 & cukup & 2,86 & Baik & 3,57 & Baik Sekali & Meningkat \\
\hline \multicolumn{8}{|l|}{$\mathrm{Jlh}$} \\
\hline $\begin{array}{l}\text { Rata- } \\
\text { rata }\end{array}$ & 2,32 & kurang & 2,66 & Cukup & 3,30 & Baik & Meningkat \\
\hline
\end{tabular}


Wesly Silalahi: Implementasi Latihan ...

\begin{tabular}{|c|c|c|c|c|c|c|c|}
\hline & \multicolumn{2}{|c|}{ Awal } & \multicolumn{2}{c|}{ Siklus1 } & \multicolumn{2}{c|}{ Siklus 2 } \\
\hline Nilai & Keterangan & $\begin{array}{c}\text { Jumlah } \\
\text { Mahasiswa }\end{array}$ & $\begin{array}{c}\text { Persentase } \\
\text { Perilaku } \\
\text { Belajar }\end{array}$ & $\begin{array}{c}\text { Jumlah } \\
\text { Mahasiswa }\end{array}$ & $\begin{array}{c}\text { Persentase } \\
\text { Perilaku } \\
\text { Belajar }\end{array}$ & $\begin{array}{c}\text { Jumlah } \\
\text { Mahasiswa }\end{array}$ & $\begin{array}{c}\text { Persentase } \\
\text { Perilaku } \\
\text { Belajar }\end{array}$ \\
\hline $0,00-2,59$ & Kurang & 28 & 77,78 & 18 & 50 & 0 & 0 \\
\hline $2,60-2,79$ & Cukup & 4 & 11,11 & 5 & 13,89 & 1 & 2,78 \\
\hline $2,80-3,39$ & Baik & 4 & 11,11 & 12 & 33,33 & 19 & 52,78 \\
\hline $3,40-4,00$ & $\begin{array}{c}\text { Sangat } \\
\text { Baik }\end{array}$ & 0 & 0 & 1 & 2,78 & 16 & 44,44 \\
\hline Jumlah & & 36 & 100 & 36 & 100 & 36 & 100 \\
\hline
\end{tabular}

Lebih jelasnya peningkatan Perilaku latihan kelompok mahasiswa dapat dilihat dari rata-rata nilai observasi kondisi awal, siklus I dan pada siklus II, seperti pada gambar diagram batang dibawah ini:

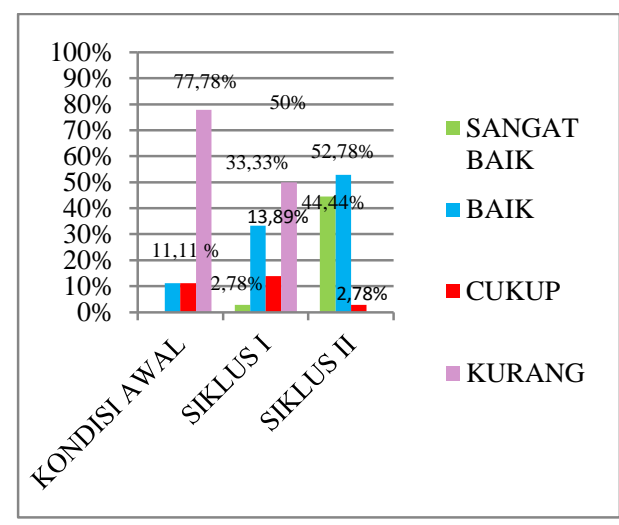

Gambar 18 : Diagram Perilaku Belajar Mahasiswa Kondisi awal, siklus I, dan siklus

Dari hasil observasi yang dilakukan dapat dilihat bahwa semua mahasiswa mengalami perubahan motivasi belajar dalam tekun menghadapi tugas, ulet menghadapi kesulitan, menunjukkan minat terhadap bermacam-macam masalah, lebih senang bekerja mandiri, tidak mudah jenuh dalam proses pembelajaran, dapat mempertahankan pendapatnya, dan senang mencari dan memecahkan masalah. Peningkatkan terjadi pada mahasiswa dikarenakan peneliti menerapkan metode latihan kelompok pada tindakan yang dilakukan pada saat pembelajaran materi lari sambung (estafet). Melalui penggunaan metode latihan kelompok dapat meningkatkan motivasi belajar mahasiswa pada "Materi Lari Sambung (estafet)".

Hasil penelitian pada saat siklus I motivasi belajar mahasiswa pada tindakan diperoleh ada 1 orang mahasiswa dari 36 orang mahasiswa yang mengalami perubahan dengan memperoleh hasil yang sangat baik dengan nilai antara 3,40-4,00 
sebesar 2,78\%. Hasil penelitian pada saat siklus I motivasi belajar mahasiswa pada tindakan diperoleh ada 1 orang mahasiswa dari 36 orang mahasiswa yang mengalami perubahan dengan memperoleh hasil yang sangat baik dengan nilai antara $3,40-4,00$ sebesar $2,78 \%$. Ada 12 orang mahasiswa dari 36 orang mahasiswa yang mengalami perubahan dengan memperoleh hasil yang baik dengan nilai antara 2,80-3,39 sebesar $33,33 \%$, dan 5 orang mahasiswa dari 36 orang mahasiswa yang memperoleh hasil yang cukup dengan nilai antara 2,602,79 sebesar $13,88 \%$, ada 18 orang mahasiswa dari 36 orang mahasiswa yang memperoleh hasil yang kurang dengan nilai antara 0,00-2,59 sebesar $50,0 \%$. Berdasarkan hasil data siklus I diperoleh dengan nilai rata-rata siswa yaitu 2,66 dengan kategori: cukup.

Dengan kesimpulan sementara bahwa penggunaan metode latihan kelompok yang dilakukan peneliti terjadi peningkatan namun masih kurang dalam meningkatkan perilaku belajar mahasiswa sehingga perlu perubahan pada siklus II.Pada tindakan siklus II memperoleh hasil perubahan perilaku belajar mahasiswa diperoleh ada 16 orang mahasiswa dari 36 orang mahasiswa yang mengalami perubahan dengan memperoleh hasil yang sangat baik dengan nilai antara
3,40-4,00 sebesar 44.44\%, Ada 19 orang mahasiswa dari 36 orang mahasiswa yang mengalami perubahan dengan memperoleh hasil yang baik dengan nilai antara 2,803,39 sebesar 52,78\%, dan ada 1 orang mahasiswa dari 36 orang mahasiswa yang memperoleh hasil yang cukup dengan nilai antara 2,602,79 sebesar $2,78 \%$. Sehingga dapat di simpulkan hasil penelitian ini dengan penerapan metode latihan kelompok yang dilaksanakan peneliti dapat meningkatkan perubahan hasil motivasi belajar mahasiswa dengan nilai rata-rata yang diperoleh mahasiswa yaitu 3,30 dengan kategori baik.

Dengan adanya data tersebut bahwa meningkatnya perilaku belajar mahasiswa dengan penerapan metode latihan kelompok berarti dapat disimpulkan bahwa metode latihan kelompok dapat dipergunakan sebagai salah satu model pembelajaran untuk meningkatkan perilaku belajar mahasiswa terutama materi lari sambung (estafet).

\section{SIMPULAN}

Dari hasil pengamatan dan data yang peneliti peroleh pada kelas B Extensi PGSD FIP Unimed Medan terhadap upaya meningkatkan perilaku belajar dengan model pembelajaran latihan 
kelompok, maka dapat ditarik beberapa kesimpulan:

1. Implementasi latihan kelompok dalam mengajarkan lari sambung (estafet) pada mahasiswa Kelas B Extensi PGSD FIP Unimed dapat meningkatkan perilaku belajar mahasiswa kearah yang lebih baik.

2. Dengan menggunakan metode Latihan kelompok dapat meningkatkan perilaku belajar mahasiswa dalam pembelajaran, karena mahasiswa secara langsung dilibatkan dalam pembelajaran.

3. Dengan diberikan kebebasan dan terbimbing dalam latihan kelompok dapat meningkatkan motivasi atau perilaku belajar karena masing-masing mahasiswa dapat mengembangkan diri tanpa terlalu terikat terhadap dosen.

Berdasarkan dari hasil penelitian yang dilakukan oleh peneliti, maka peneliti menyarankan:

1. Setiap dosen pada PGSD FIP Unimed dalam mengajarkan lari sambung (estafet) diharapkan menggunakan model pembelajaran dengan latihan kelompok sebagai salah satu alternatip untuk meningkatkan perilaku belajar mahasiswa.

2. Setiap dosen perlu memvariasikan model atau metode mengajar agar mahasiswa tidak merasa bosan dan memiliki motivasi belajar yang baik.

3. Setiap dosen perlu memberi kebebasan belajar dan berlatih tetapi terbimbing kepada mahasiswa agar dapat mengembangkan potensi dan kreativitas mahasiswa dalam belajar dan berlatih.

4. Bagi dosen agar selalu memperhatikan motivasi belajar atau perilaku belajar pada setiap pembelajaran agar dapat menunjang hasil belajar yang baik.

\section{DAFTAR RUJUKAN}

Abdullah, Arma dan Manadji, agus. 1994.

Dasar-dasar

Pendidikan Jasmani. Jakarta: Dirjen Dikbud.

Depdiknas. 2004. Kurikulum 2004. Standar Kompetensi Mata Pelajaran Pendidikan Jasmani Sekolah Dasar Dan Madrasah Ibtiddaiyah. Jakarta: Depdiknas.

Djamarah, Syaiful Bahri dan Zain, Aswan. 2002. Strategi Belajar Mengajar. Jakarta: Rineka Cipta.

Dick, W and Carey, L. 1978. The Sistematic Design of Instruktion. London: Scott Foresment and Company. 
Dimyati dan Mudjiono. 1999. Belajar dan Pembelajaran. Jakarta: Rineka Cipta.

Haryati, Mimin. Model \& Teknik Penilaian Pada Tingkat Satuan Pendidikan. Jakarta: Gaung Perkas Press.

Roestiyah. 2008. Strategi Belajar Mengajar. Jakarta: Rineka Cipta.

Sanjaya, Wina. 2007. Strategi Pembelajaran Berorientasi Standar Proses Pendidikan. Jakarta: Kencana.

Soemo, Sasmito Soenardi. 1988. Dasar Proses dan Efektivitas Belajar Mengajar Pendidikan Jasmani. Jakarta: Depdikbud.

Sugel, S. 1997. Statistik Non Parametrik. Jakarta: Gramedia.

Syarifuddin, Aip dan Muhadi. 1991. Pendidikan Jasmani dan Kesehatan. Jakarta: Dirjen Dikti Depdikbud.

Syarifuddin. 1977. Pokok-pokok Pengembangan Pembeljaran Pendidikan Jasmani. Jakarta: Depdikbud.
Sardiman. 2009. Interaksi dan Motivasi Belajar Mengajar. Jakarta: Grafindo Persada.

Slameto . 2003. Belajar dan FaktorFaktor yang Mempengaruhinya. Jakarta: Rineka Cipta.

Sudjono, Anas. 2009. Pengantar Evaluasi Pendidikan. Jakarta: Grafindo Persada.

Sanjaya, Wina. 2008. Strategi Pembelajaran Jakarta: Kencana Prenada. 